\title{
Cadaveric Oath - Perceptions of First Year Medical Students
}

\author{
Harsha Atul Keche1, Preeti Prabhakar Thute², Ujwal Lehandas Gajbe³, \\ Atul Shankarrao Keche ${ }^{4}$ Darshna Gulabrao Fulmali ${ }^{5}$
}

\begin{abstract}
${ }^{1}$ Department of Anatomy, Jawaharlal Nehru Medical College, Sawangi (M), Wardha, Maharashtra, India. ${ }^{2}$ Department of Anatomy, Jawaharlal Nehru Medical College, Sawangi (M), Wardha, Maharashtra, India. ${ }^{3}$ Department of Anatomy, DMMC, CMS, SMHRC, Wanadongri, Nagpur, Maharashtra, India. ${ }^{4}$ Department of Forensic Medicine \& Toxicology, All India Institute of Medical Sciences, Bhopal, Madhya Pradesh, India. ${ }^{5}$ Department of Anatomy, Jawaharlal Nehru Medical College, Sawangi (M), Wardha, Maharashtra, India.
\end{abstract}

\section{ABSTRACT}

\section{BACKGROUND}

Cadaveric dissection is indispensable for anatomy learning. The student - cadaver relationship stabilized on humanities can serve as a simulation for future doctorpatient relationship. Hence bioethics is introduced in the medical curriculum. To achieve the goal of professionalism, cadaveric oath should be conducted on the first day of anatomy dissection, so that medical students can imbibe values like respect, gratitude, compassion, care and dignity towards their first teacher.

\section{METHODS}

This is an observational study conducted in the Department of Anatomy of J.N.M.C., Sawangi (Meghe), Wardha. On the first day of anatomy dissection, first year medical students were sensitized about the ethical approach towards cadaver. Students were given cadaveric oath. 220 students who participated in the study marked their responses to the questionnaire about the perceptions of cadaveric oath according to the 5 point Likert scale. Data was analysed statistically.

\section{RESULTS}

$172(78.18 \%)$ and $182(82.73 \%)$ students strongly agreed upon the importance of cadaveric oath in anatomy learning and that it is unique and essential aspect of the medical curriculum respectively. Students agreed that this event helped them to overcome their inhibitions and the event was heart touching and empathetic. $98.18 \%$ students strongly agreed that they should be thankful to the family members for the noble gesture of body donation. $95 \%$ students strongly agreed that they are enlightened about the importance of once lived bodies while $97.73 \%$ strongly agreed that cadaver should be treated with respect, compassion, care and dignity. 97.27\% students agreed that cadavers are their silent mentors. Students strongly agreed that cadaveric oath event should be continued for future medical undergraduates and there should be awareness about bioethical education among medical students.

\section{CONCLUSIONS}

In the present study, cadaveric oath ceremonies helped learners to develop empathy towards their silent mentors. Students strongly agreed that they will always remember the noble gesture of donors for donating their body for medical education and research which cannot be compared to any of the modern-day virtual dissection tool for anatomy learning.

\section{KEY WORDS}

Cadaveric Oath, Perceptions, Ceremony, Silent Mentor, Bioethics
Corresponding Author: Dr. Preeti P. Thute,

C/o Dr. B.C. Bakane, Tathastu, infront of Ajit Sunder Palace Apartment, Near Shanti stup, Laxminagar, Wardha, Maharashtra, 442001, India,

E-mail:b_bakane@rediffmail.com

DOI: $10.14260 /$ jemds/2020/591

How to Cite This Article:

Keche HA, Thute PP, Gajbe UL, et al. Cadaveric oath-perceptions of first year medical students. J Evolution Med Dent Sci 2020;9(37):2722-2725, 10.14260/jemds/2020/591

DOI:

Submission 12-06-2020,

Peer Review 06-08-2020

Acceptance 13-08-2020,

Published 14-09-2020.

Copyright (C) 2020 JEMDS. This is an open access article distributed under Creative Commons Attribution License [Attribution 4.0 International (CC BY 4.0)] 


\section{BACKGROUND}

In today's scenario, the doctor-patient relationship is getting worse due to lack of communication skills and empathy among medical students. ${ }^{1}$ The need of hour is to develop best doctor - patient relationship. The attainment of the best professional principles, attitudes, expertise, and conduct begin on the first day of medical college and continues throughout. ${ }^{2}$ Hence Bioethics is introduced in the medical curriculum.

Since centuries human cadaveric dissection is used as an essential teaching tool in anatomy. ${ }^{3}$ Through cadaveric dissection, students are able to get the feel of the tissues and structures which leads to direct perception and deep learning of structure of the human body. But ethical and emotional aspects of it is often missed. ${ }^{4}$ The student - cadaver relationship stabilized on humanities can serve as a simulation for future doctor-patient relationship. ${ }^{5}$ It is an important step in the medical profession. A cadaver has a fundamental moral and ethical value that necessitates a solemn attitude towards it. $^{6}$ Every human cadaver should be held in high esteem which undergoes anatomical dissection and enriches medical sciences. A cadaveric oath becomes an essential part of medical curriculum to express students respect and gratitude to the donors and their families.

A Cadaveric Oath is a pledge which the students recite on the opening day of Anatomy learning, to pay tributes to the soul, to respect the dignity and integrity of the human remains that they are about to work on. To promote humanistic values such as respect, altruism, and responsibility among students memorial ceremonies of gratitude towards cadaver donors are conducted worldwide in many medical schools. South Korea has a strong tradition of the memorial ceremonies. There are two ceremonies, one at the commencement of the course (dae - myun - sik) and the annual ceremony (gam - eun - je) with the donors' family. Besides these major events, daily at both the beginning and the end of dissections brief silent tributes are offered by the students. ${ }^{7}$ In Thailand, donors attain the highly regarded status of ajarn yai, the great teacher which is formalized in a ceremony called 'Waikhru' (honour the teacher). ${ }^{8}$

The practice of students taking an oath prior to dissecting cadavers is essential in anatomy learning and unique aspect of medical curriculum. This is an innovative idea to imbibe the importance of their first teacher and first patient in the form of a cadaver. This approach will allow students to implement and practice humanistic and ethical values indispensable for laying a foundation for their clinical training and adequate future professional practice of medicine. The present study was carried out with the aim to sensitize the first year medical students about ethical approach towards the cadaver and comprehend them that the main ethical concern of cadaver dissection lies in respect to human life. The perceptions of students about cadaveric oath event were studied after sensitization.

\section{METHODS}

This study was conducted in the Department of Anatomy, J.N.M.C. Sawangi (Meghe), Wardha after obtaining IEC (Institutional Ethical Committee) clearance. Interactive lecture about the ethical approach towards cadaver was delivered on the first day of anatomy dissection. First year medical students were first sensitized how to respect the cadaver after that they were given cadaveric oath by the faculties. Written consent was obtained from 220 students who participated in the study. Questionnaire about the perceptions of cadaveric oath event was given to students. Students marked their responses according to the 5 point Likert scale. With the help of questionnaire required information was collected.

\section{Statistical Analysis}

Statistical analysis was done by using descriptive statistics. $95 \%$ confidence interval for the mean was calculated. The percentage of the students who were strongly agreed to the questionnaire was calculated as shown in the Table 1. Software used in the analysis was SPSS 24.0 version.

\section{RESULTS}

220 students of first year MBBS participated in the present study. After cadaveric oath perceptions of students were obtained. A cadaveric oath is important in anatomy learning was strongly agreed by $172(78.18 \%)$ students and its mean was $4.65 \pm 0.76$. Mean of 'Cadaveric oath is unique and essential aspect of the medical curriculum' was $4.73 \pm 0.67$ and was strongly agreed by $182(82.73 \%)$ students. 160 (72.73\%) students strongly agreed that this event helped them to overcome their inhibitions and its mean was $4.45 \pm 1.01$.

\begin{tabular}{|c|c|c|c|}
\hline Questionnaire & $\begin{array}{l}\text { Mean } \\
( \pm S D)^{a}\end{array}$ & $\begin{array}{c}95 \% \text { CI for } \\
\text { the Mean }\end{array}$ & $\begin{array}{c}\text { Strongly Agreed } \\
\text { Students }(\%)^{c}\end{array}$ \\
\hline Q1 - There is importance of cadaveric oath in anatomy learning. & $4.65 \pm 0.76$ & $4.55-4.75$ & $172(78.18 \%)$ \\
\hline 2 - It is a unique and essential aspect of the medical curriculum. & $4.73 \pm 0.67$ & $4.64-4.82$ & $182(82.73 \%)$ \\
\hline Q3 - Cadaveric oath event helps you to overcome your inhibitions. & $4.45 \pm 1.01$ & $4.32-4.59$ & $160(72.73 \%)$ \\
\hline Q4 - Cadaveric oath event is heart touching \& empathetic. & $4.35 \pm 1.06$ & $4.21-4.50$ & $141(64.09 \%)$ \\
\hline Q5 - You should be thankful to the family members for their noble gesture of donating body for medical teaching \& research. & $4.98 \pm 0.13$ & $4.66-4.99$ & $216(98.18 \%)$ \\
\hline Q6 - After Cadaveric oath you are enlightened about the importance of once lived bodies. & $4.95 \pm 0.21$ & $4.92-4.97$ & $209(95 \%)$ \\
\hline Q7 - Cadaver should be treated with respect, compassion, care \& dignity. & $4.97 \pm 0.18$ & $4.94-4.99$ & $215(97.73 \%)$ \\
\hline Q8 - You accept the fact that cadavers are your silent mentors. & $4.97 \pm 0.16$ & $4.95-4.99$ & $214(97.27 \%)$ \\
\hline Q9 - Cadaveric oath event should be continued for future undergraduate medical students. & $4.81 \pm 0.49$ & $4.74-4.87$ & $189(85.91 \%)$ \\
\hline Q10 - There should be awareness about bioethical education (ethics of medical and biological research) among medical students. & $4.89 \pm 0.40$ & $4.83-4.94$ & $203(92.27 \%)$ \\
\hline
\end{tabular}

Mean calculated using 5-point Likert scale $\mathbf{-}-1=$ strongly disagree, $2=$ disagree, $3=$ neutral, 4 = agree, $5=$ strongly agree; $95 \% \mathrm{Cl} \mathbf{b}$ $95 \%$ Confidence interval; Percentage that responded "strongly agree"c. 


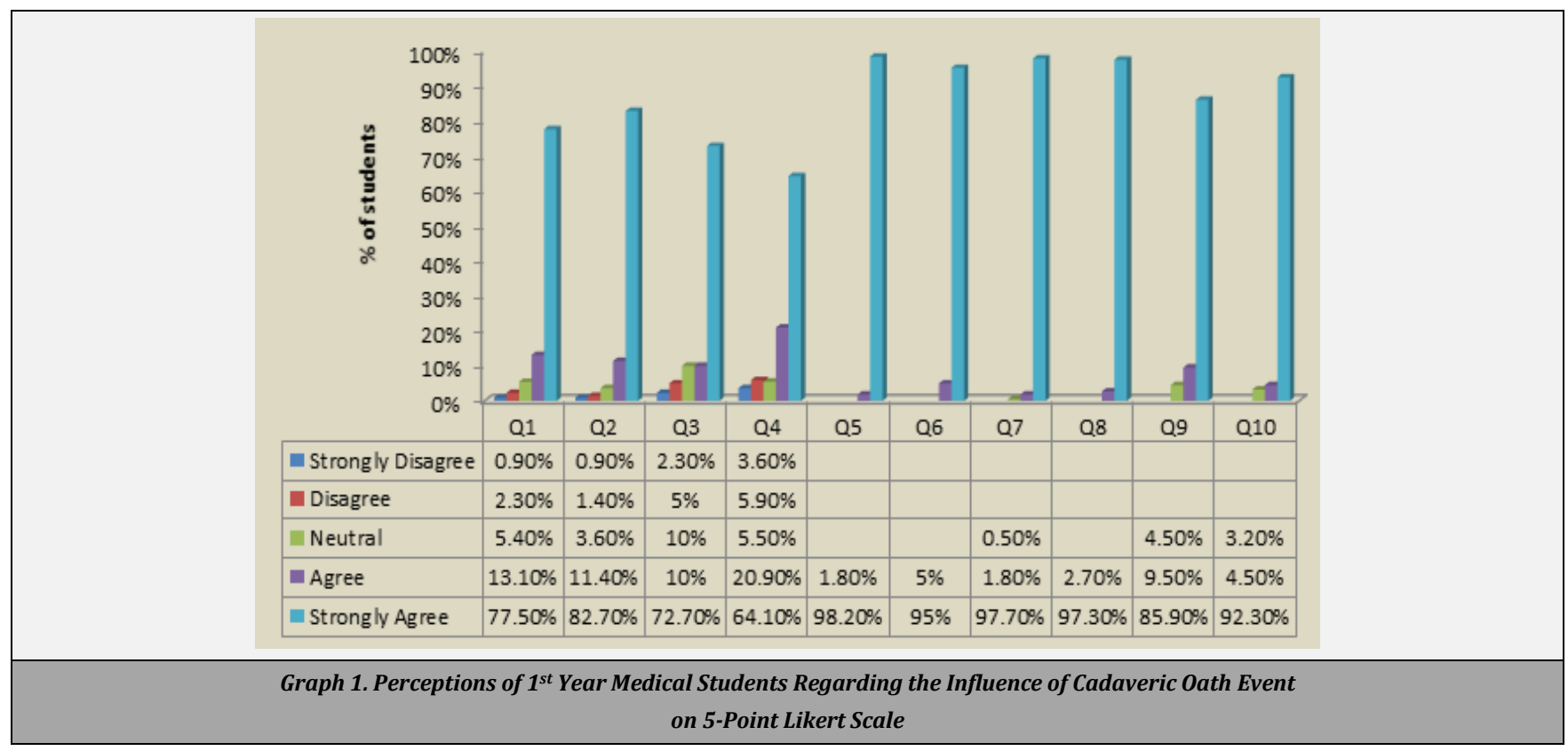

Mean of 'Cadaveric event is heart touching and empathetic' was $4.35 \pm 1.06$ and strongly agreed by 141 (64.09\%) students. About 216 (98.18 \%) students strongly agreed that they should be thankful to the family members for the noble gesture of body donation and its mean was $4.98 \pm 0.13$. Mean of 'Students enlightened about the importance of once lived bodies' and 'Cadaver should be treated with respect, compassion, care and dignity' was $4.95 \pm 0.2$ and $4.97 \pm 0.18$ and was strongly agreed by 209 (95\%) and 215 (97.73\%) students respectively. $97.27 \%$ students agreed that 'Cadavers are their silent mentors' and its mean was $4.97 \pm 0.16$. 'Cadaveric oath event should be continued for future medical undergraduates' and 'There should be awareness about the bioethical education (ethics of medical and biological research) among medical students' was strongly agreed by $189(85.91 \%)$ and $203(92.27 \%)$ students and their mean was $4.81 \pm 0.49$ and $4.89 \pm 0.40$ respectively.

\section{DISCUSSION}

Anatomy is a rigorous course which requires great dedication and devotion. To study human anatomy, cadavers are required in all disciplines of medical science. Cadaver-based anatomical education is a prerequisite for optimal training and is necessary for apprehension of the multidimensional body, learning the basic language of medicine and for development of future doctor-patient relationship. ${ }^{9}$ So, it becomes an essential part that students should start their anatomy dissection classes with a cadaveric oath thanking the almighty for giving them a human body to learn from.

In the present study 172 (78.18\%) students strongly agreed that cadaveric oath is important in anatomy learning and that it is a unique and essential aspect of the medical curriculum was strongly agreed by $182(82.73 \%)$ students. The domains of attitude and communications with emphasis on ethics need to be taught directly and explicitly throughout the undergraduate curriculum for which MCI implemented attitude, ethics and communication (ATECOM) module. ${ }^{10}$ In Thailand, two ceremonies are held to define an ethical framework related to the dissection courses: the dedication ceremony - some days before the first course session and the cremation ceremony - at the end of the course. ${ }^{8}$ A dignified "silent mentor" initiation ceremony is conducted in medical schools of Taiwan to strengthen student's medical humanity and to increase their learning attitudes. ${ }^{11}$ In South Korea, anatomy professors provide lectures regarding professional attitudes while dealing with human cadavers on the first day of ceremony (dae - myun - sik). ${ }^{7}$

About 160 (72.73\%) students strongly agreed that this event helps them to overcome their inhibitions and 141 (64.09 $\%)$ students strongly agreed that event is heart touching and empathetic. Halpern J commented that students should be sensitized so that they can develop an emotional attachment with the cadaver which can help them to understand the psychosocial factors contributing to a patient's illness. ${ }^{12}$ Andrea Oxley da Rocha et al in their study remarked that empathy is an essential attitude for future medical professionals enabling them to provide more humanistic medical care. 13

In the present study about 209 (95\%) students strongly agreed that they should be thankful to the family members for their noble gesture of donating body for medical teaching \& research. In the study conducted by Monika Lalit about 136 (98.55 \%) students, while in study of Saha et al $98 \%$ students had a sense of gratitude to people who donated their dead bodies.9,14 The unique concept of "Donor Luncheon," is introduced in the University of Oklahoma College of Medicine where prior to anatomy dissection students meet the families of the donor which enables them to maintain humanistic attitudes at the beginning of their medical career. ${ }^{12}$

In the ATECOM competencies for Indian Medical Graduate competency number AN82.1: Demonstrate respect and follow the correct procedure when handling cadavers and other biological tissues is included under the topic of Ethics in Anatomy. ${ }^{15}$ In the present study 209 (95\%) students strongly agreed that they are enlightened about the importance of once lived bodies while 215(97.73 \%) students strongly agreed that cadaver should be treated with respect, compassion, care and dignity. In the study conducted by the Monika Lalit, cadavers were once living humans like them was agreed by 116 (80.06 
$\%)$ students, while $132(95.66 \%$ ) had sympathy and respect for them. ${ }^{9}$ Dinesh Kumar et al in their study commented that after the disrobing ceremony they summarised the responses of students in four themes affective, cognitive, behavioural and moral. In the moral theme students responded that they had empathy and compassion for the cadaver. ${ }^{5}$

"Mortui Vivos Docent" is a classical latin quote which means "The Dead teach the Living" which is true for the cadaver as the first teacher where it teaches the budding doctors. In the present study cadavers are their silent mentors was agreed by 214 (97.27 \%) students. The cadaveric oath pledge or recitation has a role in developing empathy for cadaver as silent teachers was realized by 138 (100\%) respondents in the study conducted by the Monika Lalit et al. ${ }^{9}$ In the ATECOM competencies for Indian Medical Graduate, Module 1.5: The cadaver as our first teacher is the learning modules of MBBS professional year 1 is recently included.10 Anne D Souza in their prospective, multimethod study of "Cadaver as a first teacher" CrAFT module, the students revealed that the module nurtured the values of professionalism, human values and empathy. ${ }^{16}$ In Thailand Waikhru marks the beginning of the course so that students can establish a new relationship between them and their ajran yai (great teacher). During the course they always referred cadaver as the ajarn yai, never as sop (cadaver) and greeted them with a wai (Thai greeting bow). ${ }^{8}$ In the ceremony of Taiwan each student express their thoughts in the letter which is offered to the donor's relatives to develop long term bonds between them and their silent mentors. ${ }^{11}$

In the present study Cadaveric oath event should be continued for future medical undergraduates and there should be awareness about the bioethics (ethics of medical and biological research) education among medical students was strongly agreed by $189(85.91 \%)$ and 203(92.27 \%) respectively. Bioethical education is the best way to achieve the goal of professionalism. It should start at the beginning of anatomy learning by taking cadaveric oath. Cadaver has an important role in ethics education. Cadaver ceremonies can be ritualistically conducted for future medical students to help them cherish the privilege of dissection which is not available to other professionals. ${ }^{17}$ They may also serve as a powerful means to define the atmosphere and provide an ethical framework around dissection. ${ }^{8}$ To achieve the goal of professionalism, cadaveric oath is included in the bioethical education as cadaveric dissection is indispensable for anatomy learning.

\section{CONCLUSIONS}

Cadaveric oath ceremony has helped medical students to imbibe values like respect, gratitude, compassion, care and dignity towards their first teacher. It will fulfill students' duties in a professional manner without personal feelings or emotions. The noble gesture of donors of donating their body for medical education and research will always be remembered which cannot be compared to any of the modern day virtual dissection tool for anatomy learning.

Cadaveric oath ceremonies help learners to develop empathy towards their silent mentors. It has the potential to inculcate humanistic values among medical students which will contribute in making the empathetic doctors of tomorrow which in turn will help in simulation of better doctor-patient relationship.

Financial or Other Competing Interests: None.

\section{REFERENCES}

[1] Gaikwad MR. Cadaveric oath: the need of the hour. Indian J Anatomy Surg Head, Neck Brain 2017;3(2):56-7.

[2] Lala M. Cadaveric oath and its relevance in anatomy. Inter J Adv Case Reports 2016;3(6):282-5.

[3] Magee R. Art macabre: resurrectionists and anatomists. ANZ J Surg 2001;71(6):377-80.

[4] Por AF, Mostafavian Z, Chamani MAR. The Professionalism \& medical ethics education through cadaveric dissection. J Med Education \& Development Winter 2018;12(4):248-59.

[5] Kumar DV, Jayagandhi S, Nim VK, et al. Cadaver ceremonies as a foundation step for bioethics: a phenomenological study. Int J Anat Res 2017;5(3.2):4195-203.

[6] Sawant SP, Rizvi S. Moral \& Ethical values of cadaver procurement for dissection. Scholar J Applied Med Sci 2015;3(29):1043-5.

[7] Chang HJ, Kim HJ, Rhyu IJ, et al. Emotional experiences of medical students during cadaver dissection and the role of memorial ceremonies: a qualitative study. BMC Med Educ 2018;18(1):255.

[8] Winkelmann A, Gulder FH. Cadavers as teachers: the dissecting room experience in Thailand. BMJ 2004;329(7480):1455-7.

[9] Lalit M, Mahajan A, Arora AK, et al. Attitude and response of first-year medical students towards cadaver, dissection and subject of anatomy: a qualitative study. AMEI's Current Trends in Diagnosis \& Treatment 2018:2(2):1219.

[10] Attitude, Ethics and Communication (AETCOM) Competencies for the Indian Medical Graduate. Graduate Med Educ Regulations (GMR 2017).

[11] Chiou RJ, Tsai PF, Han DY. Effects of a silent mentor initiation ceremony and dissection on medical students humanity and learning. BMC Res Notes 2017;10(1):483.

[12] Ghosh SK. Human cadaveric dissection: a historical account from ancient Greece to the modern era. Anat Cell Biol 2015;48(3):153-69.

[13] da Rocha AO, Maues JL, Chies GA, et al. Assessing the impact of a ceremony in honor of the body donors in the development of ethical and humanistic attitudes among medical students. Anat Sci Educ 2020;13(4):467-74.

[14] Saha N, Chaudhari S, Singh MM. Attitude of first year medical students in dissection hall. J Dent Med Sci 2015;14(5):74-8.

[15] Competency based undergraduate curriculum for the Indian medical graduate - Vol I - (2018)

[16] Souza AD, Prabhath S, Pandey AK, et al. Cadaver as a first teacher: a module to learn the ethics and values of cadaveric dissection. J Taibah University Med Sci 2020;15(2):94-101.

[17] Kumar D, Murugan M, Devi R. Anatomists' prespective on boosting bioethics in medical education. Research \& Humanities in Medical Education 2019;6:21-6. 